\title{
Pola Resistansi Antibiotik Bakteri Penyebab Infeksi Saluran Kemih di Puskesmas Ibrahim Adjie Kota Bandung
}

(Antibiotic Resistance Pattern of Bacteria Causing Urinary Tract Infection in Ibrahim Adjie Health Center, Bandung City)

\section{Tina Rostinawati ${ }^{1 *}$, Barolym Tri Pamungkas $^{1}$, Moelyono Moektiwardojo $^{1} \&$ Anas Subarnas ${ }^{2}$}

${ }^{1}$ Departemen Biologi, Fakultas Farmasi Universitas Padjadjaran, Jl. Raya Bandung-Sumedang km21, Jatinangor, Sumedang, Jawa Barat ${ }^{2}$ Departemen Farmakologi dan Farmasi Klinik, Fakultas Farmasi Universitas Padjadjaran, Jl. Raya Bandung-Sumedang km21, Jatinangor, Sumedang, Jawa Barat

\begin{abstract}
The bacteria that cause urinary tract infections (UTIS) have developed resistance to various antibiotics. Data about the pattern of bacterial resistance need to be updated to ensure proper antibiotic administration. The research aimed to identify and perform the pattern of bacterial resistance from UTI patients at the Ibrahim Adjie Health Center, Bandung City. The urine samples of 9 suspected UTI patients were determined for the number of bacterial colonies. It turned out 3 samples whose number of bacterial colonies fulfil the UTI criteria i.e above $10^{5} \mathrm{cfu} / \mathrm{ml}$. The isolates were subsequently determined for Gram bacteria, isolation of bacterial chromosome DNA, amplification of 16S rRNA gene, DNA sequencing, and antibiotic resistance tests against penicillin, penicillin + $\beta$-lactamase inhibitor, cephalosporin (generation 1,2,3,4), fluoroquinolone, aminoglycoside and carbapenem. Three isolates (P1, P2, P3) were genetically identified as Escherichia coli. P1 was resistant to penicillin, penicillin $+\beta$-lactamse inhibitor, cephalosporin generation 1 and fluoroquinolone. P2 was just resistant to penicillin. P3 was resistant to penicillin, penicillin $+\beta$-lactamse inhibitor, cephalosporin (generation 1,2,3,4) and fluoroquinolone. These E. coli had developed resistance to penicillin, penicillin $+\beta$-lactamase inhibitor, cephalosporin (generation 1,2,3,4) and fluoroquinolone. Aminoglycoside and carbapenem still have activity against these E. coli.
\end{abstract}

Keywords: bacteria; UTI; isolation; identification; resistency.

ABSTRAK: Bakteri penyebab Infeksi saluran kemih (ISK) telah mengalami resistansi terhadap berbagai antibiotik. Pola resistansi bakteri tersebut perlu diperbaharui datanya untuk memastikan pemberian antibiotik yang tepat. Tujuan penelitian ini adalah untuk mengidentifikasi dan melihat pola resistansi bakteri penyebab ISK di Puskesmas Ibrahim Adjie Kota Bandung. Koloni bakteri yang berasal dari urin 9 pasien suspect ISK ditumbuhkan dan hanya sampel yang berasal dari 3 pasien memenuhi persyaratan terindikasi ISK karena adanya jumlah koloni di atas $10^{5} \mathrm{cfu} / \mathrm{ml}$. Selanjutnya dilakukan penentuan Gram bakteri, isolasi DNA total kromosom bakteri, amplifikasi gen pengkode 16S rRNA, sekuensing (penentuan urutan nukleotida) dan uji resistansi terhadap antibiotik golongan penisilin, penisilin+inhibitor $\beta$-laktamase, sefalosporin (generasi 1,2,3,4), fluorokuinolon, aminoglikosida dan karbapenem. Hasil penelitian menunjukkan tiga isolat (P1,P2,P3) yang teridentifikasi secara genetik Escherichia coli. Isolat P1 resisten terhadap penisilin, penisilin+inhibitor $\beta$-laktamase, sefalosporin generasi 1 dan fluorokuinolon. isolat $\mathrm{P} 2$ resisten terhadap penisilin. Isolat P3 resisten terhadap penisilin, penisilin+inhibitor $\beta$-laktamase, sefalosporin (generasi 1,2,3,4) dan fluorokuinolon. E. coli penyebab ISK telah mengalami resistansi terhadap antibiotik penisilin, penisilin+inhibitor $\beta$-lactamase, sefalosporin (generasi $1,2,3,4)$ dan fluorokuinolon. Aminoglikosida dan karbapenem masih memiliki aktivitas terhadap ketiga isolat E. coli resisten.

Kata kunci: bakteri; ISK; isolasi; identifikasi; resistansi.

\section{Pendahuluan}

Secara global, infeksi saluran kemih masih menjadi masalah kesehatan yang penting dan banyak dijumpai di berbagai unit pelayanan kesehatan dasar hingga subspesialistik [1]. Infeksi Saluran Kemih (ISK) merupakan penyakit infeksi kedua tersering setelah infeksi saluran pernafasan yaitu sebanyak 8,1 juta kasus per tahun.
JumLah pasien ISK perempuan dua kali lipat lebih banyak dibandingkan pasien laki-laki yaitu $1,2 \%$ berbanding $0,6 \%$ [2]. Infeksi saluran kemih disebabkan karena adanya mikroorganisme pada saluran kemih, termasuk kandung kemih, prostat, ginjal dan saluran

\section{Article history}

Received: 12 Okt2020 Accepted: 04 Des 2020 Published: 30 April 202

Access this article

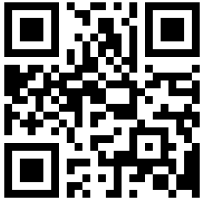


pengumpulan. Sebagian besar ISK disebabkan oleh bakteri, meskipun kadang-kadang jamur dan virus dapat merupakan agen etiologi ISK [3]. Infeksi saluran kemih didefinisikan sebagai kondisi dimana saluran kemih terinfeksi oleh patogen yang menyebabkan peradangan atau inflamasi [4]. Kunci diagnosa ISK biasanya didasarkan pada gejala dan pemeriksaan adanya mikroorganisme dalam urin. Kriteria umum untuk diagnosis ISK dengan adanya bakteri lebih dari $100.000 \mathrm{cfu} / \mathrm{mL}$ [5]. Bakteri yang paling banyak menginfeksi saluran kemih antara lain E. coli, Klebsiella pneumoniae, Proteus mirabilis, Enterococcus faecalis dan Staphylococcus saprophyticus [3].

E. coli adalah patogen dominan di dalam ISK disertai patogen berikutnya adalah E. faecalis, $K$. pneumoniae dan $P$. mirabilis. Amoksisilin dan sefuroksim sudah berkurang aktivitasnya terhadap E. coli. Sedangkan siprofloksasin sangat aktif melawan patogen ISK tersebut [6]. Pasien ISK di suatu rumah sakit di India Selatan menunjukkan resistansi yang meningkat terhadap siprofloksasin [7]. Di Bangladesh data resistansi antibiotik amoksisilin, kotrimoksazol dan asam nalidiksat juga telah terjadi terhadap E. coli dan Klebsilia spp. Namun imipenem masih aktif terhadap bakteri tersebut [8]. Di Indonesia, E. coli juga merupakan bakteri penyebab ISK terbanyak [9-11]. Sedangkan pada suatu rumah sakit di Banda Aceh bakteri penyebab ISK yang terbanyak adalah Pseudomonas aeruginosa [12]. Bakteri penyebab ISK pada beberapa rumah sakit di Indonesia juga telah menunjukkan resistansi terhadap antibiotik kotrimoksazol, seftriakson, ampisilin, sefiksim tetapi masih sensitif terhadap amikasin, imipenem, gentamisin, cefiksim, sefalosporin dan kuinolon [13-16].

Pola bakteri penyebab ISK dan sensitivitas bakteri terhadap antimikroba akan berperan dalam keberhasilan pengobatan ISK. Beberapa strain bakteri E. coli telah menghasilkan enzim extended-spectrum beta-lactamases (ESBL)
[17]. Hal Ini dapat membuat bakteri resistansi terhadap antibiotik tertentu, sehingga bakteri terus berkembang biak dan menyebar. Berdasarkan hal tersebut, pola bakteri dan sensitivitasnya terhadap antimikroba penting untuk disampaikan hasilnya secara berkala berkala kepada rumah sakit melaui program PPRA (Program Pengendalian Resistansi Antibiotik). Pola resistansi bakteri mengalami perubahan ditempat dan waktu yang berbeda sehingga perlu dilakukan analisis pola dan sensitivitas bakteri terhadap antimikroba yang selalu diperbarui [18].

\section{Metode Penelitian}

\section{Isolat Bakteri}

Bakteri uji yang akan digunakan adalah bakteri yang diambil dari spesimen urin pasien ISK yang dirawat di Puskesmas Ibrahim Adjie Kota Bandung. Dengan kriteria inklusi pasien: usia 17 - 55 tahun, laki-laki dan perempuan, pasien ISK yang berobat di Puskesmas Ibrahim Adjie Kota Bandung, pasien yang tidak menderita infeksi bakteri lainnya. Sedangkan kriteria eksklusi pasien: pasien yang tidak terdiagnosa menderita ISK, pasien yang tidak patuh mengikuti pengobatan ISK dan pasien yang susah diambil spesimen urinnya. Penelitian ini telah disetujui etiknya dari komisi etik Universitas Padjadajran dengan Nomor : 51/ UN6.KEP/EC2018.

\section{Pengumpulan Sampel Bakteri}

Sampel bakteri diambil dari spesimen urin pasien ISK dengan cara dikumpulkan dalam pot plastik, diambil sebanyak $10 \mathrm{~mL}$ kemudian dimasukkan ke dalam media Mueller Hilton Broth (MHB) (Merck®, USA) yang telah disterilkan dan diinkubasi pada suhu $37^{\circ} \mathrm{C}$ selama $18-24$ jam.

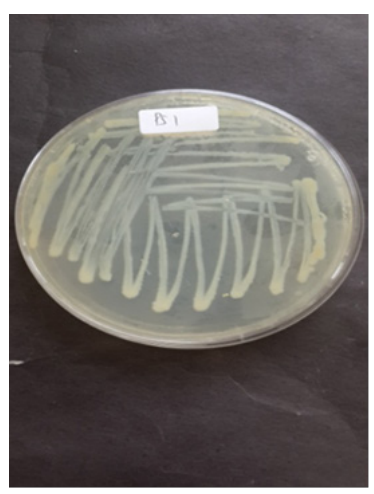

P1

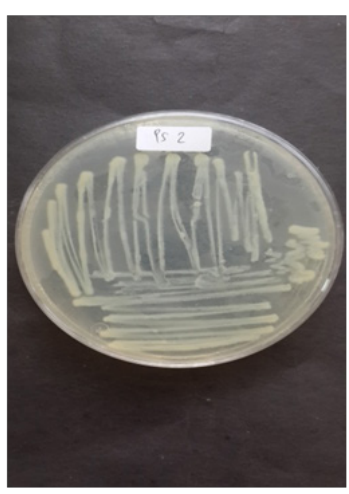

P2

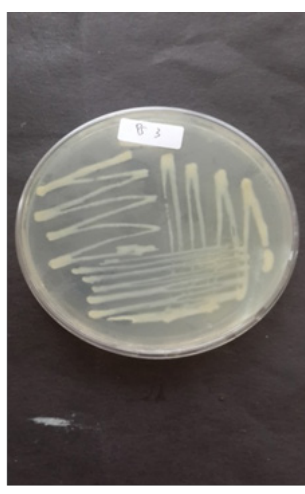

P3

Gambar 1. Isolat klinis tunggal bakteri ISK. P1=pasien 1, P2=pasien2, P3=pasien 3 


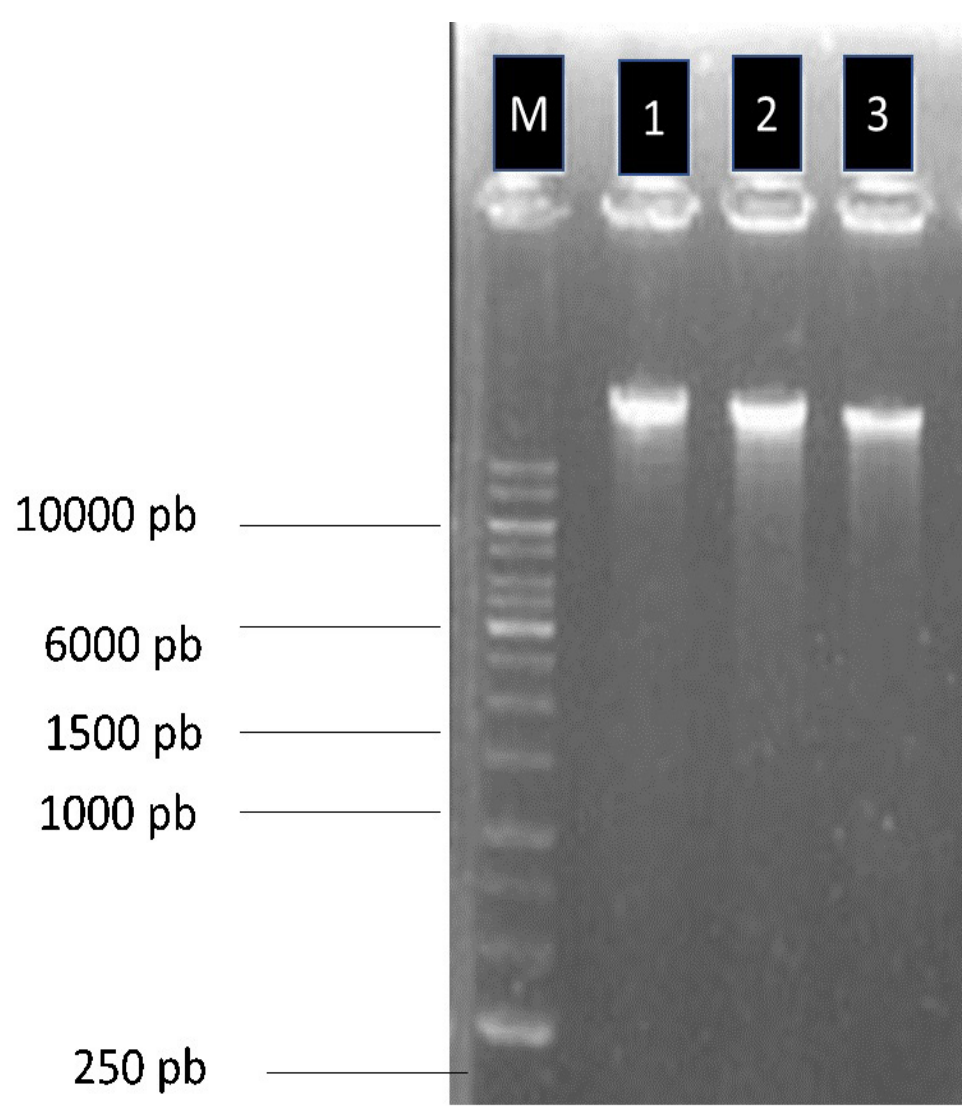

Gambar 2. Hasil visualisasi isolasi DNA total. $\mathrm{M}=$ Marker DNA ( $\mathrm{pb}=$ pasangan basa, $1=$ isolat $\mathrm{P} 1,2=$ isolat $\mathrm{P} 2$, $3=$ isolat $\mathrm{P} 3$

\section{Isolasi Bakteri Penyebab Infeksi Saluran Kemih}

Bakteri ditanam pada media Muller Hilton Agar (MHA) (Merck®, USA) dengan metode cawan gores. Media MHA steril dituangkan ke dalam cawan petri sebanyak $20 \mathrm{~mL}$ dan dibiarkan hingga padat. $1 \mathrm{~mL}$ sampel urin ditambahkan $9 \mathrm{~mL}$ air suling steril. Kemudian 1 ose suspensi bakteri diambil dan digoreskan pada media MHA yang telah padat. Media MHA tersebut diinkubasi pada suhu $37^{\circ} \mathrm{C}$ selama 18-24 jam. Selanjutnya dilakukan pemisahan koloni untuk ditumbuhkan pada media MHA yang baru. MHA dan MHB merupakan media yang dapat menghasilkan hasil yang reproducible dan mengandung inhibitor sulfonamide, trimethoprim dan tetracycline yang rendah.

\section{Pewarnaan Gram Bakteri}

Identifikasi bakteri dilakukan dengan melihat morfologi koloni bakteri dan pewarnaan gram. Pewarnaan gram dilakukan untuk mengetahui bakteri tersebut bakteri negatif atau positif [19].

\section{Isolasi DNA Total Isolat Bakteri}

Isolasi DNA total dilakukan dengan mengikuti protokol isolasi GeneJETTMGenomic DNA Purification
Kit ${ }^{\circledR}$ (Thermo Fisher Scientific, USA). DNA sampel selanjutnya disimpan pada suhu $-20{ }^{\circ} \mathrm{C}$ [20].

\section{Amplifikasi Gen 16S rRNA}

Amplifikasi gen 16S rRNA dilakukan dengan metode PCR (T100TM Thermal Cycler from Bio-Rad, USA). Primer yang digunakan dalam amplifikasi gen 16S rRNA adalah primer $1492 \mathrm{R}$ (5' GGTTACSTTGTTACGAC 3') (Macrogen, South Korea) dan primer 27 F (5' AGAGT'TTGATCTGGCTCAG 3') (Macrogen, South Korea). Komponen PCR $50 \mu \mathrm{L}$ yang digunakan terdiri dari $2 \mu \mathrm{L}$ primer $1492 \mathrm{R} \mu \mathrm{M} ; 2 \mu \mathrm{L}$ primer $27 \mathrm{~F} 15 \mu \mathrm{M} ; 1$ $\mu \mathrm{L}$ dNTP $10 \mu \mathrm{M} ; 6 \mu \mathrm{L}$ dapar PCR 10x (mengandung 20 $\mathrm{mM} \mathrm{MgCl} 2) ; 0,4 \mu \mathrm{L}$ Taq polimerase $5 \mathrm{u} / \mu \mathrm{L} ; 2 \mu \mathrm{L}$ DNA sampel dan 36,6 $\mu \mathrm{L}$ air bebas nuklease. Semua komponen dimasukkan ke dalam tabung eppendroff $200 \mu \mathrm{L}$ dan dihomogenkan. Tabung dimasukkan ke dalam thermocyler, suhu dan waktu amplifikasi diatur dengan tahap denaturasi awal $94{ }^{\circ} \mathrm{C}$ selama 1 menit, penempelan (annealing) $55^{\circ} \mathrm{C}$ selama 1 menit, pemanjangan (extension) fragmen DNA 72 ${ }^{\circ} \mathrm{C}$ selama 1 menit, reaksi dilakukan sebanyak 32 siklus. Pemanjangan fragmen diakhiri post PCR $72{ }^{\circ} \mathrm{C}$ selama 10 menit [21]. 


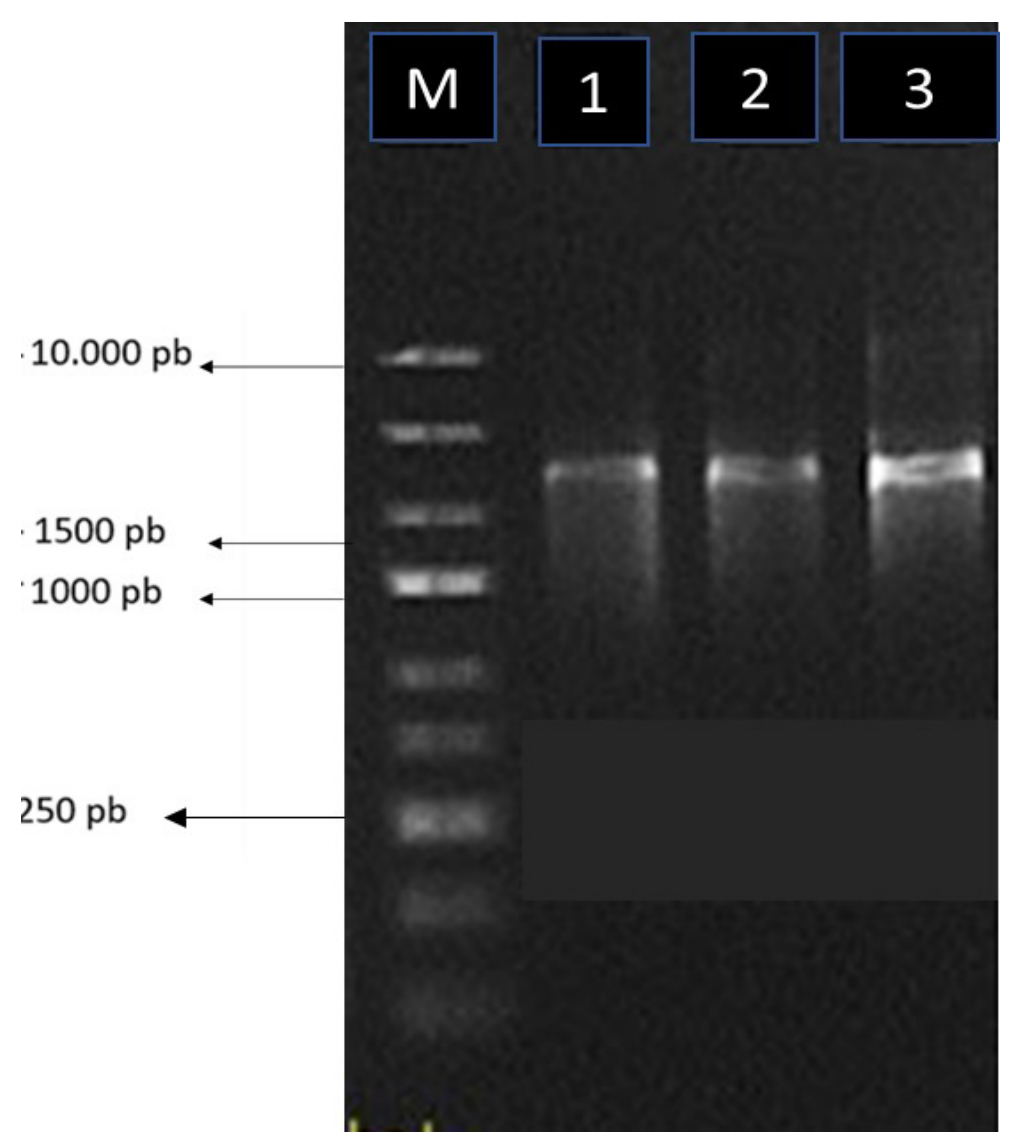

Gambar 3. Visualisasi DNA hasil amplifikasi gen pengkode 16S rRNA, M = Marker (pb=pasangan basa, 1=isolat P1, 2=isolat P2, $3=$ isolat P3

\section{Elektroforesis DNA Bakteri}

Elektroforesis DNA bakteri dilakukan menggunakan agarosa 1\%. Elektroforesis dilakukan pada $100 \mathrm{~V}$ selama 40 menit dan pita DNA yang terbentuk diamati dengan mini trans-iluminator UV [22].

\section{Sekuensing Fragmen 16S rRNA Satu Arah}

Sekuensing DNA dilakukan di Macrogen Korea Selatan. Pembacaan analisis sekuensing fragmen DNA dilakukan dengan bantuan Basic Local Aligment Search Tool (BLAST) urutan nukleotida yang kemudian dicocokkan dengan data base yang tersedia pada situs hhtp://blast. ncbi.nlm.nih.gov.

\section{Uji Resistansi Antibiotik terhadap Isolat Bakteri}

Sampel bakteri dari pasien diuji resistansi terhadap beberapa antibiotik ISK. Media MHA cair (suhu 40-50 $\left.{ }^{\circ} \mathrm{C}\right)$ ditambahkan ke dalam cawan petri yang telah berisi suspensi bakteri dengan konsentrasi $10^{5} \mathrm{CFU} / \mathrm{mL}$, lalu campuran tersebut disebar di atas media dan didiamkan. Setelah sedikit membeku, paper disk yang telah berisi antibiotik sebanyak $10 \mu \mathrm{L}$ dengan masing - masing konsentrasinya ditempelkan pada media agar. Cawan ditutup dan diinkubasi pada suhu $37{ }^{\circ} \mathrm{C}$ selama $18-24$ jam. Zona inkubasi (zona bening) yang terbentuk diukur menggunakan jangka sorong. Bakteri dari sampel urin ISK diuji resistansinya terhadap beberapa antibiotik yaitu ampisilin (10 $\mu \mathrm{g})$, amoksisilin-asam klavulanat (20/10 $\mu \mathrm{g})$, ampisilin - sulbaktam $(10 / 10 \mu \mathrm{g})$, piperasilin - tazobaktam $(100 / 10 \mu \mathrm{g})$, tikarsilin-asam klavulanat $(75 / 10 \mu \mathrm{g})$, sefazolin $(30 \mu \mathrm{g})$, sepalotin $(30 \mu \mathrm{g})$, sefuroksim $(30 \mu \mathrm{g})$, sefotaksim $(30 \mu \mathrm{g})$, seftazidim $(30 \mu \mathrm{g})$, sefepim $(30 \mu \mathrm{g})$, amikasin $(30 \mu \mathrm{g})$, gentamisin $(10 \mu \mathrm{g})$, tobramisin $(10 \mu \mathrm{g})$, asam nalidiksat $(30 \mu \mathrm{g})$, ciprofloksasin $(5 \mu \mathrm{g})$, levofloksasin $(5 \mu \mathrm{g})$, ofloksasin $(5 \mu \mathrm{g})$, imipenem $(10 \mu \mathrm{g})$,dan meropenem $(10 \mu \mathrm{g})$ [23].

\section{Hasil dan Diskusi}

Sampel bakteri diambil dari urin 9 pasien yang telah terdiagnosa ISK di Puskesmas Ibrahim Adjie Kota Bandung atas dasar surat rekomendasi izin penelitian Nomor : 070/15642-Dinkes dan pasien telah setuju untuk 


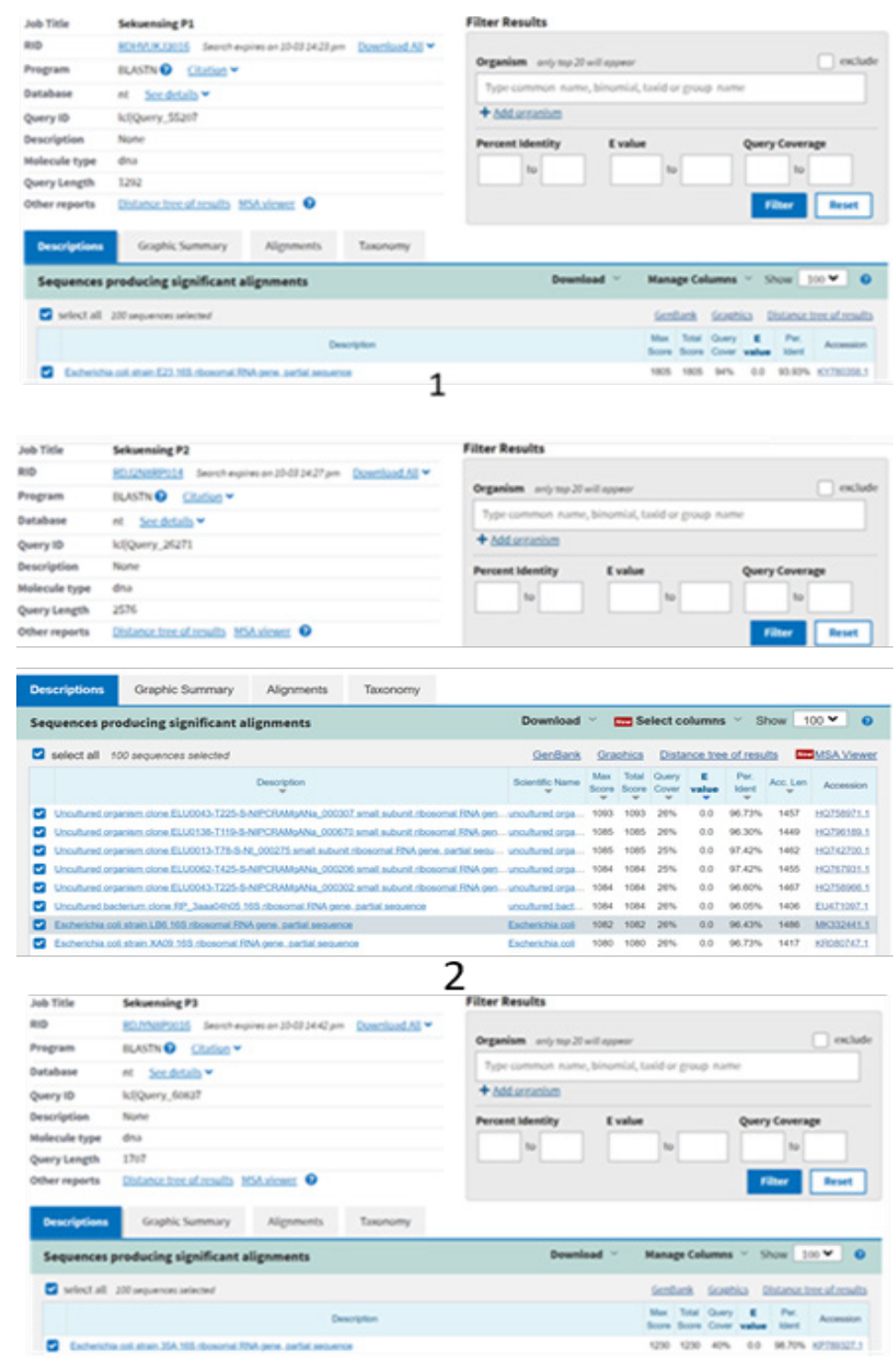

3

Gambar 4. Cuplikan data hasil BLAST sekuens isolat bakteri. 1=isolat P1, 2=isolat P2, 3=isolat P3

ikut serta dalam penelitian dengan mengisi lembar informed consent. Setelah diamati hanya 3 pasien saja yang memenuhi kriteria umum untuk terdiagnosis ISK dengan adanya lebih dari 100.000 CFU/mL urin [5]. Isolat hasil pemisahan dapat dilihat pada Gambar 1.

Hasil pewarnaan isolat bakteri penyebab ISK pada P1, P2 dan P3 teridentifikasi bakteri Gram negatif yaitu menunjukkan hasil berwarna merah setelah dilakukan pewarnaan Gram [20]. Ketiga isolat bakteri tersebut teridentifikasi sebagai E. coli setelah dilakukan isolasi DNA total (Gambar 2), amplifikasi gen 16s rRNA (Gambar 3) dan sekuensing. Hasil isolasi DNA total (kromosom) isolat bakteri menunjukkan ukuran lebih besar dari 10.000 pb. E. coli memiliki ukuran kromosom $4.6 \mathrm{mpb}$ (Gambar 2) (http://www.ncbi.nlm.nih.gov/). Ukuran amplifikasi gen 16S rRNA dari ketiga isolat menunjukkan ukuran \pm 1.500 $\mathrm{pb}$ (Gambar 3). Dengan menggunakan pasangan primer 27F dan 1492R didapatkan ukuran DNA $\pm 1.500 \mathrm{pb}$ [21]. Urutan DNA yang diperoleh kemudian dicocokkan dengan database yang terdapat pada situs http://blast. ncbi.nlm.nih.gov dengan bantuan (BLAST). Hasil blast sekuensing dari ketiga isolat menunjukkan homologi 93\%, 96\% dan 98\% terhadap E. coli untuk isolat P1, P2 dan P3 (Gambar 4).

Isolat E. coli P1 menunjukkan resistansi terhadap antibiotik $\beta$-laktam golongan penisilin, penisilin+inhibitor $\beta$-laktamase, seflosporin generasi 1 dan florokuinolon (Tabel 1). Isolat E. coli P2 hanya resistansi terhadap 
Tabel 1. Hasil uji resistansi antibiotik pada isolat P1, P2 dan P3

\begin{tabular}{|c|c|c|c|}
\hline Antibiotika & P1 & $\mathbf{P 2}$ & P3 \\
\hline Ampisilin & $\mathrm{R}$ & R & $\mathrm{R}$ \\
\hline Amoksisilin-asam klavulanat & S & । & 1 \\
\hline Ampisilin-sulbaktam & R & । & $\mathrm{R}$ \\
\hline Piperasilin-tazobaktam & S & S & I \\
\hline Tikarsilin-asam klavulanat & । & । & $\mathrm{R}$ \\
\hline Sefazolin & R & । & $\mathrm{R}$ \\
\hline Sefalotin & R & । & $\mathrm{R}$ \\
\hline Sefuroksim & S & S & $\mathrm{R}$ \\
\hline Sefotaksim & S & s & $\mathrm{R}$ \\
\hline Seftazidim & S & S & $\mathrm{R}$ \\
\hline Sefepim & S & S & $\mathrm{R}$ \\
\hline Amikasin & S & S & S \\
\hline Gentamisin & S & S & S \\
\hline Tobramisin & S & S & S \\
\hline Asam nalidiksat & R & S & $\mathrm{R}$ \\
\hline Siprofloksasin & । & । & $R$ \\
\hline Levofloksasin & S & S & $\mathrm{R}$ \\
\hline Ofloksasin & S & S & $\mathrm{R}$ \\
\hline Imipenem & S & S & S \\
\hline Meropenem & $S$ & $S$ & $S$ \\
\hline
\end{tabular}

Keterangan : $\mathrm{R}=$ Resisten, $\mathrm{I}=$ Intermediet, $\mathrm{S}=$ Sensitif

antibiotik $\beta$-laktam golongan penisilin (Tabel 1). Sedangkan isolat $E$. coli $\mathrm{P} 3$ telah resistansi terhadap antibiotik $\beta$-laktam golongan penisilin, penisilin+inhibitor $\beta$-laktamase, sefalosporin generasi 1, 2, 3, 4, dan florokuinolon (Tabel 1). Ketiga isolat ini masih sensitif terhadap antibiotik $\beta$-laktam golongan karbapenem dan aminoglikosida.

ESBL merupakan enzim yang menyebabkan bakteri tahan terhadap antibiotik golongan $\beta$-laktam, sefalosporin dan monobaktam. Ketiga isolat memiliki resistansi terhadap antibiotik penisilin yang keberadaan gen pengkode ESBL perlu diidentifikasi. Berdasarkan studi literatur maka tipe enzim yang resistansi terhadap jenis antibiotik ini adalah ESBL tipe TEM [24]. Hampir 90\% E. coli yang resistansi terhadap ampisilin memproduksi enzim TEM [25]. Untuk isolat P1 dan P3 memiliki karakter yang juga tahan terhadap inhibitor $\beta$-laktamase. Berdasarkan studi literatur enzim yang bertanggungjawab untuk karakter ini adalah IRT (inhibitor-resistant TEM $\beta$-lactamase). IRT ini ditemukan terutama di isolat klinis E. coli dan juga strain K. pneumoniae,
Klebsiella oxytoca, P. mirabilis, and Citrobacter freundii [26]. Untuk suatu isolat yang memiliki resistansi terhadap sefalotin, seftazidim dan sefotakzim seperti isolate P1 dan P3 jika merujuk terhadap penelitian sebelumnya isolat yang demikian memiliki enzim OXA, SHV, dan CTX-M yang bertanggungjawab untuk karakter resistansi tersebut [24]. Isolat P1 dan P3 juga menunjukkan resistansi terhadap antibiotik flurokuinolon. Berdasarkan studi terhadap isolat E. coli ISK gen yang bertanggungjawab terhadap resistansi terhadap fluorokuinolon adalah gyr A dan parC [27].

Pola resistansi E. coli ISK seperti pada penelitian ini juga terdapat pada suatu studi di Amerika Serikat yang menyatakan bakteri penyebab ISK 15,7\% adalah E. coli. Bakteri-bakteri penyebab ISK $24 \%$ telah resistansi terhadap levofloksasin dan sulfametoksazolko-trimetropim dan juga sebagian menunjukkan telah resistansi terhadap karbapenem [27]. Begitu juga yang terjadi di pusat kesehatan Denver Health Colorado, kasus resistansi E. coli ISK terhadap fluorokuinolon juga 
meningkat sejak mulai digiatkannya penggunaan antibiotik tersebut pada tahun 1999 ketika ko-trimoksazol telah mengalami resistansi [29]. Suatu studi yang mempelajari kejadian resistansi siprofloksasin selama 2004-2014 dari publikasi menyimpulkan telah terjadi peningkatan resistansi terhadap antibiotik golongan flurokuinolon tersebut selama 10 tahun [30].

Di Indonesia, ISK paling banyak disebabkan oleh E. coli $[9,10,31]$. Di Rumah Sakit PKU Muhammadiyah Yogyakarta E. coli penyebab ISK masih sensitif terhadap imipenem dan sudah mengalami resistansi terhadap siprofloksasin, gentamisin, trimetroprim-sulfametoksazol, amoksisilin dan sefiksim [30]. Sedangkan E. coli yang diisolasi dari pasien ISK di RSUD Arifin Achamd Pekanbaru sudah reisiten terhadap ampisilin, sefalotin, sefotaksim, seftriakson, sefaleksin dan tetrasiklin [11].

\section{Kesimpulan}

Isolat bakteri pasien ISK di Puskesmas Ibrahim Adjie Kota Bandung merupakan bakteri E. coli. Bakteri tersebut tersebut telah memiliki pola resistansi meluas terhadap ampisilin, ampisilin+inhibitor $\beta$-laktam, sefalosporin golongan 1,2,3,4 dan fluorokuinolon. Namun karbapenem dan aminoglikosida masih memiliki aktivitas terhadap bakteri tersebut.

\section{Ucapan Terima Kasih}

Ucapan terima kasih kepada Universitas Padjadjaran yang telah mendanai penelitian ini melalui Hibah Internal UNPAD Nomor:1373e/UN6.O/LT/2019.

\section{Referensi}

[1]. Kusnan A. Faktor Risiko Kejadian Infeksi Saluran Kemih pada Ibu Hamil di Laboratorium Prodia. Jurnal IImu Kesehatan. 2014;1(1): 2355-312.

[2]. Foxman B. Epidemiology of Urinary Tract Infections: Incidence, Mobidity, and Economic Costs. Dis Mon Journal. 2003;(49):53-70. doi: https://doi.org/10.1016/s0002-9343(02)01054-9.

[3]. Flores-Mireles AL, Walker JN, Caparon M, Hultgren SJ. Urinary tract infections: epidemiology, mechanisms of infection and treatment options. Nature reviews. Microbiology. 2015;13(5):269-284. doi: https://doi.org/10.1038/nrmicro3432. Epub 2015 Apr 8.

[4]. Raju CB, Tiwari SC. Urinary tract infection - A suitable approach. Lecture notes. J Ind Academy of clinical Med. 2004;2(4): 331-334.

[5]. Port,CM and Muffin G. 2009. Pathophysiology :Concepts of Altered Health States 8th Edition. Philadelphia: Lippincott Williams \& Wilkins; 2009.

[6]. Farrell DJ, Morrissey I,De Rubeis D, Robbins M, Felmingham D. A UK multicentre study of the antimicrobial susceptibility of bacterial pathogens causing urinary tract infection. J Infect. 2003;46(2):94100. doi: https://doi.org/10.1053/jinf.2002.1091.
[7]. Mandal J, Acharya NS, Buddhapriya D, Parija SC. Antibiotic resistance pattern among common bacterial uropathogens with a special reference to ciprofloxacin resistant Escherichia coli. Indian J Med Res. 2012;136(5):842-849. PMID: 23287133; PMCID: PMC3573607.

[8]. Rahman F, Chowdhury S, Rahman M, Ahmed D, Hossain, A. Antimicrobial Resistance Pattern of Gram-negative Bacteria Causing Urinary Tract Infection. S J Pharm Scices. 2009;2(1):44-50.

[9]. Sumolang SAC, Porotu'o J, Soeliongan S. Pola Bakteri Pada Penderita Infeksi Saluran Kemih Di BLU RSUP Prof. dr. R. D. Kandou Manado. Jurnal e-Biomedik (eBM). 2013;1(1): 597-601. DOI: https://doi. org/10.35790/ebm.1.1.2013.4605

[10]. Widianingsih M, de Jesus AM. Isolasi Escherichia coli Dari Urine Pasien Infeksi Saluran Kemih Di Rumah Sakit Bhayangkara Kediri. Journal of Bilogy. Al-Kauniyah.2018;11(2):99-108. DOI: https://doi. org/10.15408/kauniyah.v11i2.5899.

[11]. Yacob T, Endriani R, Hamidy MY. Resistensi Antibakteri pada Pasien Infeksi Saluran Kemih (ISK) dengan Katerisasi urin di bagian Penyakit Dalam RSUD Arifin Achmad Pekanbaru.Jurnal IImu Kedokteran Universitas Riau 2017.DOI: https://doi.org/10.26891/JIK. v5i2.2011.94-100.

[12]. Haris S, Sarindah A, Yusni, Raihan. Kejadian Infeksi Saluran Kemih di Ruang Rawat Inap Anak RSUD Dr. Zainoel Abidin Banda Aceh. Sari Pediatri. 2012;14:(4). DOI: http://dx.doi.org/10.14238/ sp14.4.2012.235-40

[13]. Septadina IS, Lestari HI, Rizka. Pola Kepekaan Bakteri Penyebab Infeksi Saluran Kemih pada Anak Terhadap Antimikroba. MKS. 2015;47(2). DOI: https://doi.org/10.36706/mks.v47i2.2748

[14]. Arivo D, Dwiningtyas AW. Pola Kepekaan Escherichia coli Penyebab Infeksi Saluran Kemih Terhadap Aantibiotik. Jurnal Farmasi Malahayati. 2019;2(1). DOI: https://doi.org/10.33024/jfm. $\underline{\mathrm{v} 2 \mathrm{i} 1.1540}$

[15]. Nua AR, fatimawti, Bodhi W. Uji Kepekaan Bakteri Yang Diisolasi Dan Diidentifikasi Dari Urin Penderita Infeksi Saluran Kemih (ISK) D RSUP Prof. Dr. R. D. Kandou Manado Terhadap Aantibiotik Cefixime, Ciprofloxacin Dan Cotrimoksazole. Pharmacon. 2016;5(4).DOI: http://ejournal.unsrat.ac.id/index.php/pharmacon/article/ view/8845

[16]. Triono AA, Purwoko AE. Efektifitas Antibiotik Golongan Sefalosporin dan Kuinolon terhadap Infeksi Saluran Kemih. Mutiara Medika. 2012;12(1):6-11. DOI: https://doi.org/10.18196/mmjkk.v12i1.994.

[17]. Biutifasar V. Extended Spectrum Beta-Lactamase (ESBL). Oceana Biomedicina Journal. 2018;1(1):1-11. DOI: http://dx.doi. org/10.30649/obj.v1i1.3

[18]. Rahardjo P, Susalit, E. Infeksi Saluran Kemih, dalam IImu Penyakit Dalam, Edisi IV. Jakarta: FKUI, 2006.

[19]. Harley JP, Prescott LM. Laboratory Exercises in Microbiology 5th Edition. The McGraw-Hill Companies; 2002

[20]. (GeneJETTMGenomic DNA Purification Kit ${ }^{\circledR}$ ). https://assets. thermofisher.com/TFS-Assets/LSG/manuals/

[21]. Weisburg WG, Barns SM, Pelletier DA, Lane DJ.16S ribosomal DNA amplification for phylogenetic study. J Bacteriol. 1991;73(2):697703. doi: https://doi.org/10.1128/ib.173.2.697-703.1991.

[22]. Sambrook J, Russell D. Molecular cloning: a laboratory manual. Cold Spring Harbor Laboratory. New York: Cold Spring Harbor Laboratory Press;2001.

[23]. Clinical and Laboratory Standards Institute (CLSI). Performance standards for antimicrobial susceptibility testing; 19th informational supplement (CLSI document M100-S19). Wayne,PA: Clinical and Laboratory Standards Institute; 2009.

[24]. Bradford PA. Extended-Spectrum Betalactamases in the 21st Century: Characterization, Epidemiology and Detection of This Important Resistance Threat. Clin Microbiol Rev. 2001;(14)4:933951. doi: 10.1128/CMR.14.4.933-951.2001.

[25]. Livermore DM. beta-Lactamases in laboratory and clinical resistance. Clin Microbiol Rev. 1995;8(4):557-84. doi: https://doi.org/10.1128/ CMR.8.4.557-584.1995. 
[26]. Carter MW, Oakton KJ, Warner M, Livermore DM. Detection of extended-spectrum $\beta$-lactamases in klebsiellae with the Oxoid combination disk method. J Clin Microbiol. 2000;38:4228-4232.

[27]. Komp Lindgren P, Karlsson A, Hughes D. (2003). Mutation rate and evolution of fluoroquinolone resistance in Escherichia coli isolates from patients with urinary tract infections. Antimicrob Agents Chemother. 2003;47(10):3222-3232. doi: 10.1128/aac.47.10.32223232.2003.

[28]. Critchley IA, Cotroneo N, Pucci MJ, Mendes R. The burden of antimicrobial resistance among urinary tract isolates of Escherichia coli in the United States in 2017. Plos One. 2019;14(12): e0220265. https://doi.org/10.1371/journal.pone.0220265.

[29]. Johnson L, Sabel A, Burman WJ, Everhart RM, Rome M, MacKenzie TD, Rozwadowski J, Mehler PS, Price CS. Emergence of fluoroquinolone resistance in outpatient urinary Escherichia coli isolates. Am J Med. 2008;121(10):876-84. DOI: htpps://doi. org/10.1016/i.amimed.2008.04.039
[30]. Fasugba O, Gardner A, Mitchell BG, Mnatzaganian G. (2015) Ciprofloxacin resistance in community- and hospital-acquired Escherichia coli urinary tract infections: a systematic review and meta-analysis of observational studies. BMC Infect Dis. 2015:15:545. doi: https://doi.org/10.1186/s12879-015-1282-4

[31]. Prabowo FI, Habib I. Identifikasi Pola Kepekaan dan Jenis Bakteri pada Pasien Infeksi Saluran Kemih di Rumah Sakit PKU Muhammadiyah Yogyakarta. Mutiara Medika. 2012;12(2);93-101. DOI: https://doi. org/10.18196/mmjkk.v12i2.1009

Copyright $\odot 2021$ The author(s). You are free to share (copy and redistribute the material in any medium or format) and adapt (remix, transform, and build upon the material for any purpose, even commercially) under the following terms: Attribution - You must give appropriate credit, provide a link to the license, and indicate if ade. You may do so in any reasonable manner, but not in any way that suggests the licensor endorses you or your use; ShareAlike - If you remix ransform, or build upon the material, you must distribute your contributions under the same license as the original (https://creativecommons.org/licenses/by-sa/4.0/) 